\title{
Spontaneously Hypertensive Rat Vascular Smooth Muscle Cells in Culture Exhibit Increased Growth and $\mathrm{Na}^{+} / \mathrm{H}^{+}$Exchange
}

\author{
Bradford C. Berk, Gino Vallega, * Anthony J. Muslin, Helen M. Gordon, Mitzy Canessa, “ and R. Wayne Alexander \\ Department of Medicine, *Cardiovascular and Endocrine-Hypertension Division, Brigham and Women's Hospital \\ and Harvard Medical School, Boston, Massachusetts 02115
}

\begin{abstract}
The cellular mechanisms responsible for abnormalities in spontaneously hypertensive rat (SHR) vascular smooth muscle cell (VSMC) growth and vasoreactivity are not defined: Because $\mathrm{Na}^{+} / \mathrm{H}^{+}$exchange, which we have previously demonstrated in cultured VSMC, plays an essential role in mediating growth factor responses, we hypothesized that abnormalities in SHR growth regulation might be reflected in the activity of this transporter. To test this hypothesis, we studied DNA synthesis and $\mathrm{Na}^{+} / \mathrm{H}^{+}$exchange (measured as the rate of amiloride-sensitive intracellular alkalinization or $\mathrm{Na}^{+}$influx) in early subcultures $(<6)$ of aortic VSMC from 12-wk-old SHR and Wistar Kyoto (WKY) animals. Serum-deprived SHR VSMC grew more rapidly in response to $10 \%$ serum with an increase in $\left[{ }^{3} \mathrm{H}\right]$ thymidine incorporation of $439 \%$ compared with $191 \%$ in WKY controls. Basal intracellular $\mathbf{p H}\left(\mathrm{pH}_{\mathrm{i}}\right)$ values determined by fluorescent $\mathrm{pH}$ measurements were $7.37 \pm 0.04$ and $7.27 \pm 0.03(P<0.05)$ in early passage SHR and WKY, respectively. Acid recovery (initial $\mathrm{pH}_{\mathrm{i}}=6.8$ ) by SHR VSMC was faster than by WKY VSMC as measured by alkalinization $\left(1.8 \pm 0.6\right.$ vs. $0.8 \pm 0.2 \mathrm{mmol} \mathrm{H}^{+} /$liter $\left.\cdot \mathrm{min}, P<0.05\right)$ or by amiloride-sensitive ${ }^{22} \mathrm{Na}^{+}$influx $(14.5 \pm 1.2$ vs. $4.0 \pm 0.5 \mathrm{nmol}$ $\mathrm{Na}^{+} / \mathrm{mg}$ protein $\left.\cdot \min , \boldsymbol{P}<\mathbf{0 . 0 5}\right)$. In comparison to WKY cells early passage SHR VSMC exhibited 2.5 -fold greater alkalinization and amiloride-sensitive ${ }^{22} \mathrm{Na}^{+}$influx in response to 100 nM angiotensin II. During serial passage, WKY cells acquired enhanced $\mathrm{Na}^{+} / \mathrm{H}^{+}$exchange and growth rates so that by passage 6, these differences were no longer present. These findings in early cultures of SHR VSMC, removed from the in vivo neurohumoral milieu, suggest that increased $\mathrm{Na}^{+} / \mathrm{H}^{+}$exchange in SHR may reflect alterations in $\mathrm{Na}^{+}$homeostasis that might contribute to altered SHR VSMC function such as enhanced growth and vasoreactivity.
\end{abstract}

\section{Introduction}

Despite intensive study, the cellular mechanisms that cause genetically determined elevations of blood pressure in the

Address reprint requests to Dr. Bradford C. Berk, Cardiology Division, Emory University School of Medicine, Drawer LL, Atlanta, GA 30322.

Received for publication 20 October 1987 and in revised form 30 September 1988.

J. Clin. Invest.

(c) The American Society for Clinical Investigation, Inc. $0021-9738 / 89 / 03 / 0822 / 08 \quad \$ 2.00$

Volume 83, March 1989, 822-829 spontaneously hypertensive rat (SHR) ${ }^{1}$ have not been defined. Efforts have been directed to explain alterations in intrinsic control mechanisms in blood vessels and to characterize circulating factors that might alter blood vessel function. Abnormal membrane potential (1) and enhanced $\mathrm{Na}^{+}(2,3), \mathrm{K}^{+}(4)$, and $\mathrm{Ca}^{2+}(5)$ fluxes have been observed in intact arteries but have not been unambiguously related to increased contractile responsiveness. Several investigators have shown organomegaly and increased cell growth rates in SHR animals before the appearance of increased blood pressure (6). Increased levels of circulating growth activity have been demonstrated $(7,8)$ in these animals and may cause the organ hypertrophy and hyperplasia.

Although there is substantial evidence that SHR arteries are hyperresponsive to some constrictors $(9,10)$, an additional explanation for abnormal vascular resistance is an increased vessel wall thickness, resulting in decreased luminal diameter (11). The increase in wall thickness is due to greater vascular smooth muscle cell (VSMC) mass and may be accounted for by cellular hypertrophy $(12)$ or proliferation $(13,14)$. In either instance, abnormal cell growth must be present. Yamori and colleagues $(15,16)$ demonstrated that VSMC cultured from aortae of 12- and 24-wk SHR and SHR stroke-prone rats proliferated significantly more rapidly than those from agematched Wistar Kyoto (WKY) rats. These investigators also observed that SHR VSMC maintained increased DNA synthesis at any concentration of extracellular $\mathrm{Na}^{+}(15)$. There have been few other studies that relate abnormalities of VSMC membrane cation transport to altered cell growth. Furthermore, there are few data detailing whether these alterations are related to primary VSMC genetic abnormalities or are secondary to environmental factors in the SHR milieu.

Theoretically, altered function of the $\mathrm{Na}^{+} / \mathrm{H}^{+}$exchanger might explain several abnormalities of VSMC function in the SHR. Changes in activity of the $\mathrm{Na}^{+} / \mathrm{H}^{+}$exchanger would link abnormalities in SHR growth with abnormalities in $\mathrm{Na}^{+}$homeostasis because the exchanger has been shown to be critically involved in both growth factor-stimulated cell division $(17,18)$ and agonist-stimulated $\mathrm{Na}^{+}$influx $(19,20)$. Increased $\mathrm{Na}^{+} / \mathrm{H}^{+}$exchange might result in a more sustained or more rapid mitogenic response to growth factors. Conversely, enhanced intracellular alkalinization after vasoconstrictor binding might contribute to the abnormal vasoreactivity demon-

1. Abbreviations used in this paper: BCECF, 2',7'-bis(carboxyethyl)-5 (6)-carboxyfluorescein; BCECF-AM, 2',7'-bis(carboxyethyl)-5 (6)-carboxyfluorescein acetoxymethyl ester; DMA, dimethylamiloride; $\mathrm{pH}_{\mathrm{i}}$, intracellular pH; SHR, spontaneously hypertensive rat; TBSS, buffer containing $130 \mathrm{mM} \mathrm{NaCl}, 1.5 \mathrm{mM} \mathrm{CaCl}_{2}, 5 \mathrm{mM} \mathrm{KCl}, 1 \mathrm{mM} \mathrm{MgCl}$, $20 \mathrm{mM}$ Hepes-Tris, $10 \mathrm{mM}$ glucose, pH 7.4 with $0.25 \mathrm{mg} / \mathrm{ml} \mathrm{BSA}$; VSMC, vascular smooth muscle cell; WKY, Wistar Kyoto. 
strated in SHR via effects on contractile enzyme function and $\mathrm{Ca}^{2+}$ homeostasis. As an approach to testing whether the $\mathrm{Na}^{+} / \mathrm{H}^{+}$exchanger is abnormal in the SHR, and whether such abnormalities are genetically rather than environmentally determined, we have compared $\mathrm{Na}^{+} / \mathrm{H}^{+}$exchange activity and growth in cultured SHR and WKY vascular smooth muscle.

\section{Methods}

Primary cultures of VSMC were obtained from 10-12-wk-old SHR and WKY rats. VSMC were isolated from thoracic aorta by enzymatic dissociation using techniques described previously from this laboratory (21). Stock cultures $\left(80-\mathrm{cm}^{2}\right.$ flasks) were passaged twice weekly with trypsin-EDTA and cells were grown in DME supplemented with $10 \%$ calf serum. Cells were used for experiments between the $3 \mathrm{rd}$ and 23rd passages except where indicated. For measurement of intracellular $\mathrm{pH}\left(\mathrm{pH}_{\mathrm{i}}\right)$, VSMC were grown on $12.5 \times 27 \mathrm{~mm}$ rectangular glass coverslips.

Changes in $\mathrm{pH}_{\mathrm{i}}$ in VSMC grown on coverslips were measured using the fluorescent $\mathrm{pH}$ indicator $2^{\prime}, 7^{\prime}$-bis(carboxyethyl)-5 (6)-carboxyfluorescein (BCECF) as previously described (22). Coverslips were incubated with $2 \mu \mathrm{M}$ BCECF-acetoxymethyl ester (AM) in HBSS for 30 min at $37^{\circ} \mathrm{C}$. Cells were washed and equilibrated in a balanced salt solution (TBSS) containing $130 \mathrm{mM} \mathrm{NaCl}, 1.5 \mathrm{mM} \mathrm{CaCl}_{2}, 5 \mathrm{mM} \mathrm{KCl}$, $1 \mathrm{mM} \mathrm{MgCl}, 20 \mathrm{mM}$ Hepes-Tris, $10 \mathrm{mM}$ glucose, pH 7.4, with 0.25 $\mathrm{mg} / \mathrm{ml} \mathrm{BSA}$. Studies were performed in a spectrofluorimeter (model CM-1, Fluorolog II; Spex Industries, Edison, NJ) equipped with a stirring apparatus, a thermostatted cuvette holder, a beam splitter, two excitation monochromators, and a dual-mirror chopping mechanism to allow the rapid alternating excitation of $\mathrm{BCECF}$ at two wavelengths, 505 and $455 \mathrm{~nm}$. The ratio of emitted fluorescence signals $(530 \mathrm{~nm})$ permits calculation of $\mathrm{pH}_{\mathrm{i}}$ that is independent of cell number, dye loading, and dye bleaching. Excitation and emission slits of 5.4 and 4.5 $\mathrm{nm}$, respectively, were used. The fluorescence signal was calibrated by permeabilizing the cells with $10 \mu \mathrm{M}$ nigericin in $135 \mathrm{mM} \mathrm{KCl}, 10 \mathrm{mM}$ Hepes-Tris, $\mathrm{pH} 7.4$ at the end of each experiment and a calibration curve of fluorescence versus $\mathrm{pH}_{\mathrm{i}}$ was constructed for each sample by titration with $2(N$-morphlino)ethane sulfonic acid.

For cell growth studies, SHR and WKY VSMC were plated in six-well cluster plates (Costar Corp., Cambridge, MA) at a density of $1-2 \times 10^{4}$ cells per well and incubated in DME with $10 \%$ calf serum. After $1 \mathrm{~d}$, the cells were serum deprived for 48-h in DME supplemented with $0.4 \%$ calf serum. The medium was then changed to DME with $\left.1 \mu \mathrm{Ci} / \mathrm{ml} \mathrm{[}{ }^{3} \mathrm{H}\right]$ thymidine and either 0.4 or $10 \%$ calf serum. After $24 \mathrm{~h}$, the medium was aspirated and cells were washed three times with TBSS, fixed by washing twice with ice-cold $10 \%$ TCA, washed twice with $95 \%$ ethanol, and extracted with $0.1 \mathrm{M} \mathrm{NaOH}$ for $30 \mathrm{~min}$. Aliquots were counted in a liquid scintillation counter. Cell protein was determined by the Lowry method (23).

${ }^{22} \mathrm{Na}$ influx was measured as previously described (24) in VSMC grown in 35-mm dishes at confluence. The cells were washed 3 times with Na-free TBSS (isoosmotic replacement of $\mathrm{Na}^{+}$with choline ${ }^{+}, \mathrm{pH}$ 7.0) at $37^{\circ} \mathrm{C}$. VSMC were then incubated for $25 \mathrm{~min}$ with $\mathrm{Na}^{+}$-free TBSS, pH 7.0, with $10 \mathrm{mM}$ glucose and $1 \mathrm{mg} / \mathrm{ml} \mathrm{BSA}$ to induce an intracellular acidification of $\sim 0.4 \mathrm{pH}$ units. $1.0 \mathrm{mM}$ ouabain and 0.1 $\mathrm{mM}$ bumetanide were then added to the buffer for an additional $5 \mathrm{~min}$ incubation. The medium was aspirated and an influx solution containing $2 \mu \mathrm{Ci} / \mathrm{ml}^{22} \mathrm{Na}^{+}, 1 \mathrm{mM}$ ouabain, $0.1 \mathrm{mM}$ bumetamide, and variable concentrations of $\mathrm{Na}^{+}$, choline ${ }^{+}$, and dimethylamiloride were added. ${ }^{22} \mathrm{Na}^{+}$influx was terminated by rapid aspiration of the media followed by six washes with ice-cold $0.1 \mathrm{M} \mathrm{MgCl}_{2}$. VSMC were extracted using $0.2 \%$ SDS and aliquots were counted in a gamma counter or processed for protein determinations (23).

For comparisons between SHR and WKY VSMC, a paired $t$ test (two tails) was used. Values are reported as mean $\pm \mathrm{SD}$, except where noted.
Angiotensin II and nigericin were from Sigma Chemical Co., St. Louis, MO; BCECF-AM was from Molecular Probes, Inc., Eugene, $\mathrm{OR} ;{ }^{22} \mathrm{Na}^{+}$and $\left[{ }^{3} \mathrm{H}\right]$ thymidine were from New England Nuclear, Boston, MA.

\section{Results}

(a) Cell growth and DNA synthesis in VSMC from SHR and $W K Y$. Differences in SHR and WKY VSMC growth were assessed by measuring cell number and $\left[{ }^{3} \mathrm{H}\right]$ thymidine incorporation. The addition of DME supplemented with $10 \%$ calf serum to quiescent SHR and WKY VSMC caused an increase in $\left[{ }^{3} \mathrm{H}\right]$ thymidine incorporation (Table I). This increase was significantly greater in SHR (439\% increase) compared with WKY VSMC (191\% increase) with a ratio of SHR/WKY stimulation by $10 \%$ serum of $2.41 \pm 0.5(n=3)$. Similar differences in the rate of increase of cell number were present (Fig. 1), in agreement with previous studies (15). Thus, during logarithmic growth of early passaged SHR there was a two to threefold increased rate of cell growth measured by either $\left[{ }^{3} \mathrm{H}\right]$ thymidine incorporation or cell number.

However, unlike previous investigators $(15,16)$ we found that by passage level $6-8$, the difference in growth rate became less apparent as manifest by an increase in the rate of the WKY VSMC $\left[{ }^{3} \mathrm{H}\right]$ thymidine incorporation $(222 \pm 63 \%$ increase) and a large decrease in the response of the SHR cells $(179 \pm 67 \%$ increase). The cause for the decreased SHR $\left[{ }^{3} \mathrm{H}\right]$ thymidine incorporation is uncertain, but may involve appearance of density-dependent growth inhibition at fewer cell number/ dish. The number of cells/dish at confluence increased over serial passages for both SHR and WKY, although more so for the WKY. For example, in subculture 3 at the end of logarith-

\section{Table I. Growth Responses of SHR and WKY VSMC}

A. $\left[{ }^{3} \mathrm{H}\right]$ Thymidine incorporation (\% increase over $0.4 \%$ serum control)

\begin{tabular}{cccc} 
& SHR & WKY & SHR/WKY \\
\hline S Subculture 6 & 589 & 200 & 2.95 \\
& 135 & 56 & 2.41 \\
& $\underline{594}$ & $\underline{317}$ & $\underline{1.87}$ \\
$>$ Subculture 7 & $439 \pm 264$ & $19 \underline{1 \pm 131}$ & $2.41 \pm 0.54^{*}$ \\
& 213 & 265 & 0.80 \\
& 149 & 204 & 0.73 \\
& 102 & 141 & 0.72 \\
& $\underline{253}$ & $\underline{278}$ & $\underline{0.91}$ \\
& $179 \pm 67$ & $222 \pm 63$ & $0.79 \pm 0.09$ \\
\hline
\end{tabular}

B. Cell number $24 \mathrm{~h}$ after logarithmic growth (no./dish $\times 10^{-3}$ )

\begin{tabular}{lrr} 
& SHR & WKY \\
\hline$\leq$ Subculture 6 & $97 \pm 31(n=3)^{*}$ & $30 \pm 20(n=3)$ \\
$>$ Subculture 7 & $154 \pm 29(n=3)$ & $108 \pm 35(n=3)$
\end{tabular}

SHR and WKY cells were incubated in six-well dishes (Costar Corp.) at 1-2 $\times 10^{4}$ cells/well. $\left[{ }^{3} \mathrm{H}\right]$ Thymidine incorporation was determined on cells made quiescent by $48 \mathrm{~h}$ incubation in $0.4 \%$ serumDME during the logarithmic growth phase. Cell counts were performed on cells $24 \mathrm{~h}$ after the end of logarithmic growth. Values are the mean $\pm S D$ of three wells and represent data obtained from serial passage (3-23) of one set of primaries. Similar data were observed with one other set of primaries. $\left({ }^{*} P<0.05\right.$ vs. WKY.) 


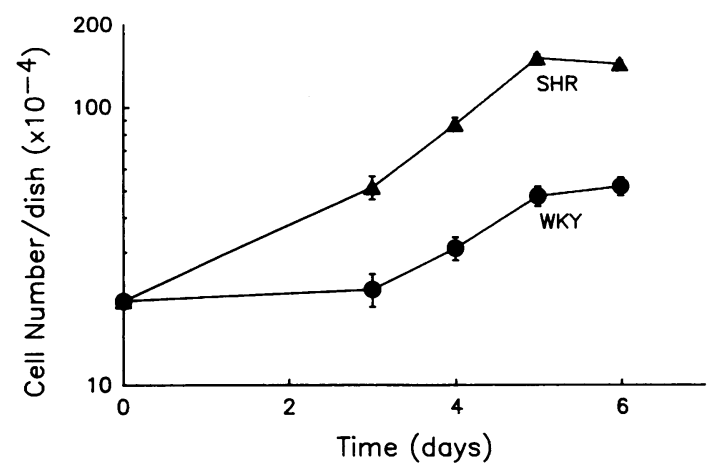

Figure 1. Proliferation of cultured SHR and WKY VSMC stimulated by $10 \%$ serum. Cells were replicate plated at $2 \times 10^{4}$ cells per $35-\mathrm{mm}$ dish in $10 \%$ calf serum-DME. After $1 \mathrm{~d}$, the medium was changed to $0.4 \%$ calf serum-DME. $2 \mathrm{~d}$ later, the medium was changed to DME with $10 \%$ calf serum. Each data point is the mean \pm SD from three dishes.

mic growth there were $105 \times 10^{4} \mathrm{SHR}$ cells $/ 35 \mathrm{~mm}$ dish compared with $27 \times 10^{4} \mathrm{WKY}$ cells $/ 35 \mathrm{~mm}$ dish, whereas in subculture 22 there were $137 \times 10^{4} \mathrm{SHR}$ cells/dish compared with $105 \times 10^{4} \mathrm{WKY}$ cells/dish. These differences in cell density at confluence may play a role in the biochemical differences observed in the two cell types.

To determine whether the differences in cell growth reflected an alteration in density-dependent growth inhibition as might occur if the SHR cells were significantly smaller than WKY cells we measured mean cell volume electronically using a FACS II cell analyzer. Although the SHR VSMC were 5\% smaller than the WKY cells $(P>0.1$, data not shown), this small change in volume would be unlikely to account for the nearly threefold difference in cell number at confluence in the early passage SHR cells.

(b) Intracellular $p H$, cell buffering power, and alkalinization rate. SHR VSMC have an increased permeability to $\mathrm{Na}^{+}$ and exhibit an increased growth response compared with WKY over a wide range of extracellular $\mathrm{Na}^{+}$concentrations $(3,15)$. Recently, enhanced $\mathrm{Na}^{+} / \mathrm{H}^{+}$exchange has been observed in lymphocytes from SHR (25). Because we and others have demonstrated the presence of such an exchange mechanism in cultured VSMC, responsive to both growth factors and vasoconstrictors $(22,26)$, it seemed likely that there would be differences in $\mathrm{Na}^{+} / \mathrm{H}^{+}$exchange activity in SHR and WKY VSMC. Initial characterization of the exchanger was performed by measurement of $\mathrm{pH}_{\mathrm{i}}$ in cultured VSMC using the fluorescent dye, BCECF. After cells were placed in the spectrofluorimeter, $\mathrm{pH}_{\mathrm{i}}$ spontaneously declined by $0.1-0.2 \mathrm{pH}$ units before stabilizing after $\sim 10 \mathrm{~min}$. The resting $\mathrm{pH}_{\mathrm{i}}$ values determined after the initial decline for cells at passages $<6$ were 7.37 $\pm 0.04(n=19)$ and $7.27 \pm 0.03(n=19)$ for SHR and WKY VSMC, respectively $(P<0.05$, Table II). At passages $>7$, the values were $7.53 \pm 0.03(n=22)$ and $7.46 \pm 0.03(n$ $=22)$, respectively $(P<0.05)$. To ensure that the SHR and WKY cells were in the same growth state for $\mathrm{pH}$ and $\mathrm{Na}^{+}$ influx measurements, we routinely performed cell counts and studied the VSMC during the plateau phase after logarithmic growth. In the early subcultures this method resulted in different numbers of cells on each dish, approximately two to threefold more SHR than WKY cells (see Table I and Fig. 1). During later passages cell numbers became equivalent.
Table II. Intracellular $\mathrm{pH}$ and $\mathrm{Na}^{+} / \mathrm{H}^{+}$Exchange Activity of SHR and WKY VSMC

\begin{tabular}{|c|c|c|}
\hline & SHR & WKY \\
\hline \multicolumn{3}{|l|}{ A. Basal $\mathrm{pH}_{\mathrm{i}}$} \\
\hline$<$ Subculture $6(n=19)$ & $7.37 \pm 0.04^{*}$ & $7.27 \pm 0.03$ \\
\hline$>$ Subculture $7(n=22)$ & $7.53 \pm 0.03^{*}$ & $7.46 \pm 0.03$ \\
\hline \multicolumn{3}{|l|}{ B. Buffering capacity } \\
\hline $\mathrm{pH}_{\mathrm{i}}=6.8\left(\mathrm{mmol} \mathrm{H} \mathrm{H}^{+} /\right.$liter $\left.\cdot \mathrm{pH}\right)$ & $35.6 \pm 5.4$ & $31.2 \pm 4.5$ \\
\hline \multicolumn{3}{|l|}{ C. $\mathrm{H}^{+}$efflux rate } \\
\hline$\left(\mathrm{mmol} \mathrm{H} \mathrm{H}^{+} /\right.$liter $\left.\cdot \min \right)$ & $1.8 \pm 0.6^{*}$ & $0.8 \pm 0.2$ \\
\hline \multicolumn{3}{|l|}{$\begin{array}{l}\text { D. DMA-sensitive } \mathrm{Na}^{+} \text {influx } \\
(\text { nmol } / \mathrm{mg} \text { protein } \cdot \text { min })\end{array}$} \\
\hline$<$ Subculture 6 Acid-loaded $(n=6)$ & $12.8 \pm 4.3^{*}$ & $6.5 \pm 2.3$ \\
\hline +Ang II $(n=6)$ & $15.1 \pm 4.8^{*}$ & $8.6 \pm 1.7$ \\
\hline$>$ Subculture 7 Acid-loaded $(n=5)$ & $12.1 \pm 2.2$ & $13.0 \pm 2.8$ \\
\hline +Ang II $(n=5)$ & $19.1 \pm 6.0$ & $20.5 \pm 5.1$ \\
\hline
\end{tabular}

Measurements of buffering capacity and $\mathrm{H}^{+}$efflux rates were performed as described in Methods on cells $\leq$ subculture 6. DMA-sensitive $\mathrm{Na}^{+}$influx was measured as described in Fig. 3 for acid-loaded cells and Fig. 5 for angiotensin II stimulated cells using $100 \mathrm{nM}$ angiotensin II and $100 \mathrm{mM}$ extracellular $\mathrm{Na}^{+}$. Numbers in parentheses indicate the number of experiments with each data point performed in triplicate. (* indicates $P<0.05$ vs. WKY.)

$\mathrm{Na}^{+} / \mathrm{H}^{+}$exchange activity of SHR and WKY cells was studied by acidifying the cells using nigericin, a $\mathrm{K}^{+} / \mathrm{H}^{+}$ionophore (27), to negate the effects of differing basal $\mathrm{pH}_{\mathrm{i}}$. The cells were routinely acid loaded to an initial $\mathrm{pH}_{\mathrm{i}}$ of $\sim 6.8-7.0$ by 10 min incubation with $10 \mu \mathrm{M}$ nigericin in $\mathrm{Na}^{+}$-free TBSS, $\mathrm{pH}$ 7.0. When $\mathrm{Na}^{+}$was added to the extracellular solution, there was a rapid increase in $\mathrm{pH}_{\mathrm{i}}$; the rise being more rapid in SHR than WKY cells (Fig. 2). This $\mathrm{Na}^{+}$-dependent alkalinization was blocked in both cell types by pretreatment with $20 \mu \mathrm{M}$ dimethylamiloride (DMA) as shown in Fig. 1, suggesting that $\mathrm{Na}^{+} / \mathrm{H}^{+}$exchange mediated the increase in $\mathrm{pH}_{\mathrm{i}}$.

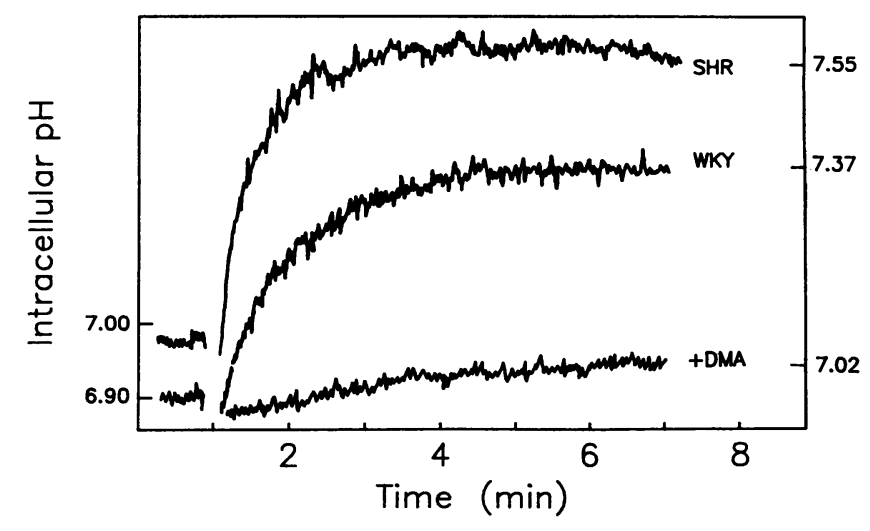

Figure 2. Alkalinization of early passage level, acid-loaded SHR and WKY VSMC. BCECF-loaded cells were acidified in $\mathrm{Na}^{+}$-free TBSS with nigericin and the ionophore was removed. Then, as indicated by the artifact, the extracellular buffer was isoosmotically replaced with $130 \mathrm{mM} \mathrm{Na}^{+}$(upper two tracings). In the lower tracing, the cells were treated with $20 \mu \mathrm{M}$ DMA for $5 \mathrm{~min}$ in $\mathrm{Na}^{+}$-free TBSS before addition of $\mathrm{Na}^{+}$(similar results were observed for both WKY and SHR cells). The traces are representative of 4 similar experiments. 
To verify that these changes in alkalinization rates were not due to alterations in intracellular buffering capacity, buffering power was measured using the $\mathrm{NH}_{4} \mathrm{Cl}$ titration technique (27). The intracellular buffering capacities for SHR and WKY VSMC (subculture 6) were the same; $27 \pm 3.4$ and $23.9 \pm 3.7$ $\mathrm{mmol} \mathrm{H}^{+}$/liter cells $\cdot \mathrm{pH}$ unit at $\mathrm{pH}_{\mathrm{i}}$ of 7.2 and $35.6 \pm 5.4$ and $31.2 \pm 4.5$ at $\mathrm{pH}_{\mathrm{i}} 6.8$, respectively $(n=3$, using 5,10 , and 20 $\mathrm{mM} \mathrm{NH}{ }_{4} \mathrm{Cl}$ ). Based on these values the maximal alkalinization rates $\left(130 \mathrm{mM} \mathrm{Na}_{0}^{+}\right.$, initial $\left.\mathrm{pH}_{\mathrm{i}}=6.8\right)$ for $\mathrm{SHR}$ and $\mathrm{WKY}$ VSMC were $1.8 \pm 0.6$ and $0.8 \pm 0.2 \mathrm{mmol} \mathrm{H} \mathrm{H}^{+} / \mathrm{liter} \cdot \min ,(n$ $=4, P<0.05)$, respectively. Thus the alkalinization rate for SHR VSMC was significantly greater than for WKY VSMC (Table II).

(c) Relationship of $\mathrm{Na}^{+} / \mathrm{H}^{+}$exchange activity to passage level. We noted that these differences in the activity of the $\mathrm{Na}^{+} / \mathrm{H}^{+}$exchanger in SHR compared with WKY VSMC were more apparent in early-passage $(<6$ subcultures) than latepassage cells. To characterize this change more precisely, we studied DMA-sensitive $(20 \mu \mathrm{M}){ }^{22} \mathrm{Na}^{+}$influx after intracellular acidification in subcultured cells ranging from passage 3 to 23 . The rate of DMA-sensitive $\mathrm{Na}^{+}$influx was greater for SHR than WKY VSMC at all subcultures $\leq 6$ (Fig. 3). However, by subculture 6-10, DMA-sensitive $\mathrm{Na}^{+}$influx in WKY cells increased to the same value as SHR cells (Table II, Fig. 3).

Titration of acid-stimulated $\mathrm{Na}^{+}$influx with increasing concentrations of DMA (Fig. 4) demonstrated that in both SHR and WKY VSMC the half-maximal inhibitory concentration $\left(\mathrm{IC}_{50}\right)$ for inhibition of $\mathrm{Na}^{+}$influx was similar (2-4 $\mu M)$. This indicates that the difference we observed in $\mathrm{Na}^{+}$ influx was not due to alterations in binding affinity of the $\mathrm{Na}^{+} / \mathrm{H}^{+}$exchanger for DMA. The DMA-insensitive $\mathrm{Na}^{+}$influx was approximately the same in both SHR and WKY cells (11.4 \pm 2.3 and $7.2 \pm 1.8$, respectively) implying that the in-

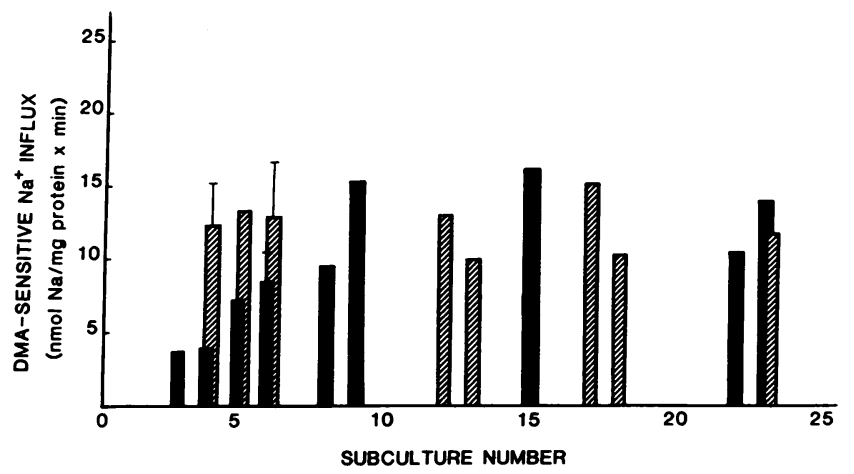

Figure 3. Effect of passage number on DMA-sensitive $\mathrm{Na}^{+}$influx in acid-loaded SHR and WKY VSMC. Cells were acid loaded in $\mathrm{Na}^{+}$free TBSS, $\mathrm{pH} 7.0$ as described above and total $\mathrm{Na}^{+}$influx in the presence or absence of $20 \mu \mathrm{M}$ DMA was assayed 2 min after placement in $100 \mathrm{mM} \mathrm{Na}^{+}$-TBSS. DMA-sensitive $\mathrm{Na}^{+}$influx is illustrated and was calculated from the difference between total $\mathrm{Na}^{+}$influx and DMA-insensitive influx. Total $\mathrm{Na}^{+}$influx ( $\mathrm{nmol} / \mathrm{mg}$ protein $\cdot \min$ ) for WKY and SHR cells at the indicated passage levels (in parentheses) were WKY: 8.4 (3), 13.9 (5), 22.2 (15), and 20 (23); SHR: 19.8 (4), $17.0(6), 21.4(17)$, and 18.6 (23). Cell passage numbers are from simultaneously prepared and serially passaged WKY and SHR VSMC. The data are representative experiments for each passage level with each determination in triplicate. Similar data were obtained for serial passages from two other sets of primaries. SD is shown for subculture $<6$ and each bar represents two to three experiments; ( $\bullet$ WKY and (回) SHR.

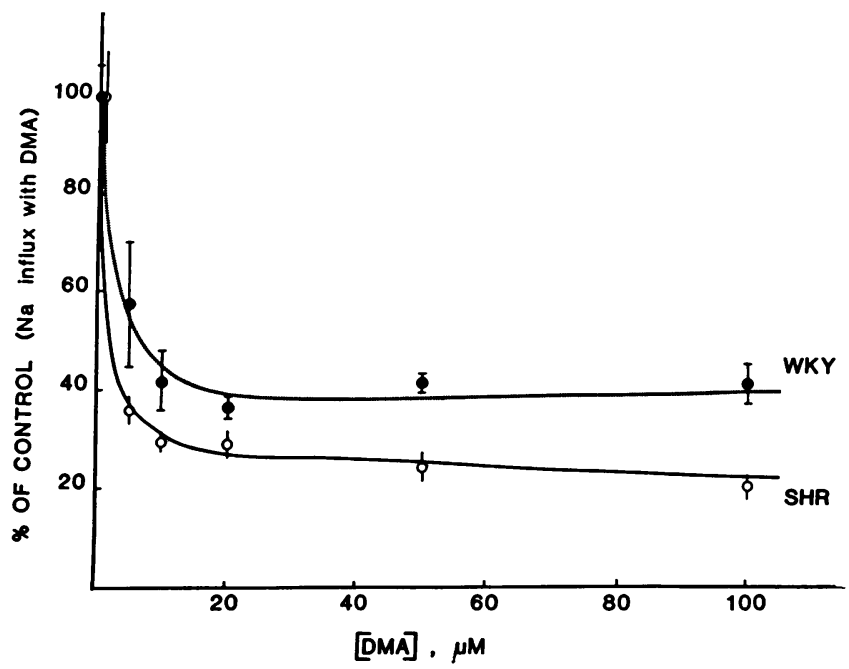

Figure 4. DMA-mediated inhibition of $\mathrm{Na}^{+}$influx into SHR and WKY VSMC. Cells (subculture 9) were acid-loaded in $\mathrm{Na}^{+}$-free TBSS, pH 7.0 as described above, and total $\mathrm{Na}^{+}$influx in the presence of varying concentrations of DMA was assayed 2 min after placement in $100 \mathrm{mM} \mathrm{Na}{ }^{+}$-TBSS.

creased ${ }^{22} \mathrm{Na}^{+}$influx was not caused by $\mathrm{Na}^{+}$entry via another transport mechanism.

(d) Agonist-stimulated $\mathrm{Na}^{+} / \mathrm{H}^{+}$exchange. To investigate whether the differences in acid-stimulated $\mathrm{Na}^{+} / \mathrm{H}^{+}$exchange were also observed in response to agonists, we studied the response to angiotensin II. In previous work $(22,26)$, angiotensin II has been found to cause an increase in DMA-sensitive $\mathrm{Na}^{+}$influx in Sprague-Dawley VSMC mediated predominantly by $\mathrm{Na}^{+} / \mathrm{H}^{+}$exchange. As shown in Fig. 5, SHR and

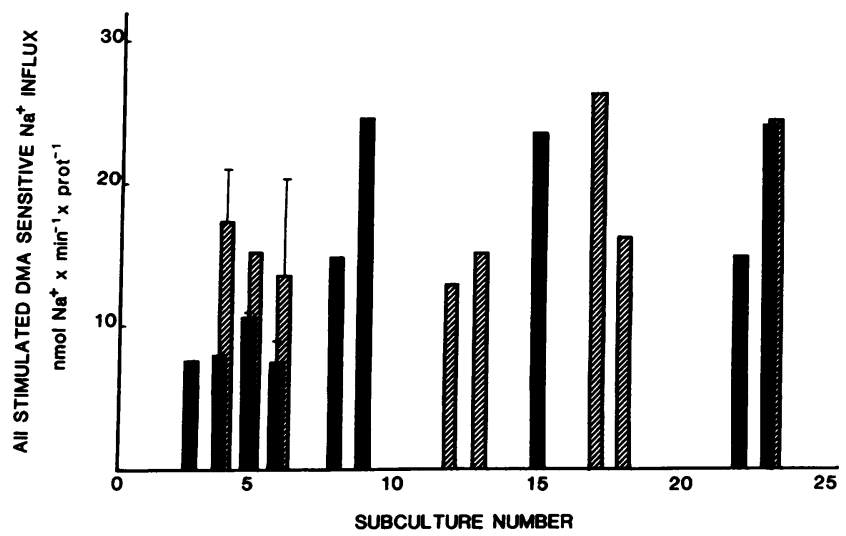

Figure 5. Effect of passage number on angiotensin II-stimulated DMA-sensitive $\mathrm{Na}^{+}$influx in SHR and WKY VSMC. Cell cultures from the same passage levels as in Fig. 3 were acid loaded in $\mathrm{Na}^{+}$free TBSS and total $\mathrm{Na}^{+}$influx in the presence or absence of $20 \mu \mathrm{M}$ DMA was measured 2 min after placement in buffer containing 100 $\mathrm{nM}$ angiotensin II and $100 \mathrm{mM} \mathrm{Na}{ }_{0}^{+}$. DMA-sensitive influx is illustrated and was calculated from the difference between total angiotensin II-stimulated $\mathrm{Na}^{+}$influx and DMA-insensitive influx. Total angiotensin II-stimulated $\mathrm{Na}^{+}$influxes ( $\mathrm{nmol} / \mathrm{mg}$ protein $\cdot$ min) for WKY and SHR cells at the indicated passage levels (in parentheses) were WKY: 14.6 (3), 18.1 (5), 37.6 (15) and 35.0 (23); SHR: 28.6 (4), $24.3(6), 39.9(17)$, and 35.3 (23). Standard deviation is shown for subculture 6 , and each bar represents the average of two to three

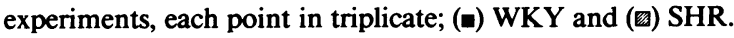


WKY VSMC exhibited large increases in $\mathrm{Na}^{+}$influx in response to $100 \mathrm{nM}$ angiotensin II that were significantly inhibited by $20 \mu \mathrm{M}$ DMA. Angiotensin II caused a significantly greater influx in early passaged SHR than in WKY, and this difference disappeared by subculture $6-10$, in parallel with the change in acid-stimulated $\mathrm{Na}^{+} / \mathrm{H}^{+}$exchange (Table II).

We and others have shown that Sprague-Dawley aortic VSMC exhibit a biphasic $\mathrm{pH}_{\mathrm{i}}$ response upon addition of angiotensin II, with initial acidification related to the transient increase in intracellular $\mathrm{Ca}^{2+}$, and a subsequent alkalinization mediated by $\mathrm{Na}^{+} / \mathrm{H}^{+}$exchange $(22,26,28)$. One possible explanation for enhanced $\mathrm{SHR} \mathrm{Na} \mathrm{Na}^{+} / \mathrm{H}^{+}$exchange in response to angiotensin II might be an increased initial acidification. As shown in Fig. 6, a biphasic $\mathrm{pH}_{\mathrm{i}}$ response was observed in both SHR and WKY VSMC in response to $10 \mathrm{nM}$ angiotensin II. These studies were carried out in cells that were not acidified by preincubation in $\mathrm{Na}^{+}$-free TBSS to increase the magnitude of the acidification response. Although there was considerable variation in the extent of the initial acidification among different cell preparations there was no significant difference between the SHR and WKY acidification responses at any passage level. However, the alkalinization response to angiotensin II was accentuated in early passage SHR cells, such as those shown in Fig. 6, with rates of $1.57 \pm 0.24$ and $1.12 \pm 0.21 \mathrm{mmol}$ $\mathrm{H}^{+} /$liter $\cdot \min \left(\right.$ at $\mathrm{pH}_{\mathrm{i}}=7.35$ and $\left.7.30 ; n=6\right)$ in SHR and WKY VSMC, respectively $(P<0.02)$. Half-maximal stimulation for both acidification and alkalinization in the two cell types in response to angiotensin II was $\sim 5 \mathrm{nM}$ (data not shown).

To investigate whether the change in agonist-mediated $\mathrm{Na}^{+} / \mathrm{H}^{+}$exchange was secondary to differences in receptor density we compared angiotensin II receptor number in cultured WKY and SHR VSMC as previously described (29). Other investigators (30) found no significant differences in angiotensin II receptor density in the mesenteric vascular bed of $\mathrm{Na}^{+}$-replete 12-wk-old SHR and WKY rats: $83 \pm 10$ and $75 \pm 6 \mathrm{fmol} / \mathrm{mg}$ protein, respectively. At low passage levels (3-6), angiotensin II receptor number was $139 \pm 68$ and $217 \pm 138 \mathrm{fmol} / \mathrm{mg}$ protein with $K_{d}$ values of $1.38 \pm 1.13$ and $1.74 \pm 1.03 \mathrm{nM}$ in SHR and WKY cells, respectively $(n=3, P$ $>0.1$ ). At higher passage levels SHR and WKY VSMC acquired increasing numbers of angiotensin II receptors; 508 and $294 \mathrm{fmol} / \mathrm{mg}$ protein, respectively, at passage 25 with similar $K_{d}$ values; 1.16 and $1.48 \mathrm{nM}$, respectively. Because all $\mathrm{Na}^{+}$ experiments except those performed specifically to test the consequences of passage level were done at low passage numbers it is unlikely that a change in receptor number was responsible for the enhanced SHR alkalinization and $\mathrm{Na}^{+}$influx responses to angiotensin II.

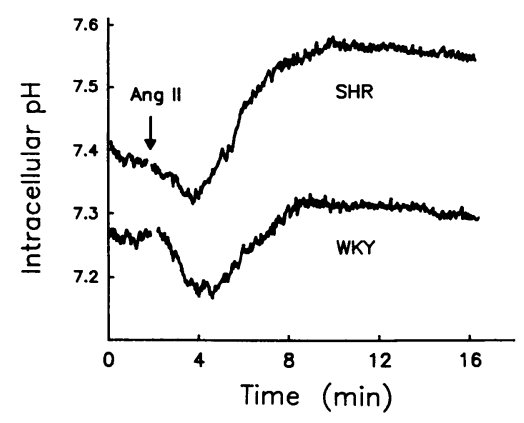

Figure 6. Angiotensin II-stimulated $\mathrm{pH}_{\mathrm{i}}$ responses in early passage (<6) SHR and WKY VSMC. BCECF-loaded cells were maintained in TBSS, pH 7.4, and where indicated by the arrow, $10 \mathrm{nM}$ angiotensin II was added. Traces are representative of at least three experiments.

\section{Discussion}

The development of hypertension in the SHR is genetically determined, but the fundamental biochemical mechanisms that result in increased vascular tone and vessel wall growth are unclear. To differentiate genetic factors from the effects of the neurohumoral milieu in vivo, we have used cultured SHR and WKY cells to analyze $\mathrm{Na}^{+} / \mathrm{H}^{+}$exchange in a setting in which the predominant determinant of function is likely to be the genetic program. The major finding of this work is that early subcultures of SHR VSMC exhibit enhanced $\mathrm{Na}^{+} / \mathrm{H}^{+}$ exchange and growth compared with WKY VSMC. In later passages, there is no difference in growth rate or $\mathrm{Na}^{+} / \mathrm{H}^{+}$exchange suggesting a functional relationship between these two parameters.

There are conflicting data as to whether the increase in VSMC mass in SHR is secondary to hyperplasia $(13,14)$ or hypertrophy (12). It is also possible that the mechanism underlying arterial wall medial hypertrophy may vary both for vessel size (conduit versus resistance vessels) and vessel location. Note that studies reported here involved aortic VSMC. The observation that serum from prehypertensive SHR, but not WKY animals stimulates Sprague-Dawley renal fragment growth in vitro suggests that a circulating humoral factor may cause abnormal SHR vessel growth (7). In addition, development of organ hypertrophy (particularly cardiac) precedes development of hypertension and a cardiac hypertrophic factor has been partially purified from $\operatorname{SHR}$ serum $(6,8)$.

Our data suggest that abnormalities in function of the $\mathrm{Na}^{+} / \mathrm{H}^{+}$exchanger may play a significant role in mediating this abnormal growth. It is of interest that angiotensin II, a potent activator of $\mathrm{Na}^{+} / \mathrm{H}^{+}$exchange in cultured VSMC $(22$, $24,26)$ has been shown to cause increased cell size and protein synthesis of cultured Sprague-Dawley aortic VSMC $(31,32)$. The findings of the present study that angiotensin II increased $\mathrm{Na}^{+}$influx and intracellular alkalinization to a greater extent in SHR than WKY VSMC suggest that the renin-angiotensin system may be involved in abnormal growth of SHR vessels. Alterations in other signal transduction mechanisms involving phospholipase $\mathrm{C}$ activity (33) or transmembrane fluxes of $\mathrm{Ca}^{2+}, \mathrm{Na}^{+}$, and $\mathrm{K}^{+}(2-5)$ may also play an important role in determining the magnitude and duration of the VSMC response to growth stimulation.

Local autocrine mechanisms have also been suggested to play a role in VSMC growth (34) and vasoreactivity (35). The presence of renin and angiotensinogen in the vessel wall (35) implies that local production of angiotensin may play a role in VSMC growth. This attractive hypothesis appears plausible based on the data discussed above and the presence of increased angiotensin II receptor number in prehypertensive 4-6-wk-old SHR vessels (30).

Our findings on VSMC growth are similar to those of Yamori and colleagues $(15,16)$, who found increased protein and DNA synthesis, as well as decreased doubling times for cultured SHR compared with WKY cells. Yamabe et al. (36) noted a tendency toward increased $\left[{ }^{14} \mathrm{C}\right]$ lysine incorporation into perfused aorta in vivo of 13-wk-old SHR rats. Finally, Haudenschild et al. (37) observed decreased doubling times for VSMC isolated from desoxycorticosterone salt sensitive, hypertensive rats suggesting that some alterations in VSMC growth may be a consequence of the hypertensive state. Interestingly, we observed a decrease in SHR $\left[{ }^{3} \mathrm{H}\right]$ thymidine incor- 
poration with serial passage (Table I, top section) that was not associated with a decrease in cell number at confluence (Table I, bottom section). This decrease likely reflects a prolongation in SHR VSMC doubling time over serial passages, although selective loss of a population of more rapidly dividing cells cannot be excluded. It is also possible that density-dependent growth inhibition of SHR cells may alter during serial passage so that higher passages exhibit increased doubling times at lower cell number. Analysis of the cell cycle population distribution (e.g. $G_{0} / G_{1}$ vs. $G_{2}$ and $S$ ) over serial passage may provide insight into the mechanism underlying these changes.

In our study there was a good correlation between the change in SHR and WKY growth rates and the kinetics of $\mathrm{Na}^{+} / \mathrm{H}^{+}$exchange (Tables I and II, Figs. 3 and 5), suggesting a causal relationship. This would be anticipated since the $\mathrm{Na}^{+} / \mathrm{H}^{+}$exchanger has been postulated to play a fundamental role in mediating mitogenic responses (17). Over serial passages we observed that the WKY cells acquired $\mathrm{Na}^{+} / \mathrm{H}^{+}$exchange and growth characteristics similar to the SHR cells. One possible explanation for this finding is that upon initial subculture the proportion of WKY VSMC expressing a "high $\mathrm{Na}^{+} / \mathrm{H}^{+}$exchange" phenotype is small, whereas the majority of SHR VSMC have this phenotype. During serial passage, the high $\mathrm{Na}^{+} / \mathrm{H}^{+}$exchange phenotype confers a selective growth advantage (38), resulting in this phenotype eventually predominating in the WKY as well. Conversely, it is possible that the decline in SHR growth (measured by $\left[{ }^{3} \mathrm{H}\right]$ thymidine incorporation) may not be related directly to the alteration observed in $\mathrm{Na}^{+} / \mathrm{H}^{+}$exchange since regulation of cell growth is extremely complex.

Another possible explanation for the relationship between cell growth rate and $\mathrm{Na}^{+} / \mathrm{H}^{+}$exchange activity is an effect of cell confluence on ion flux. Viniegra and Rabito (39) found a 40-fold increase in $\mathrm{Na}^{+} / \mathrm{H}^{+}$exchange in confluent, nonproliferating renal epithelial LLC-PK ${ }_{1 A}$ cells compared with subconfluent actively proliferating cultures. In the studies performed here we measured $\mathrm{Na}^{+} / \mathrm{H}^{+}$exchange activity in cells 24 $h$ after the end of logarithmic growth. However, in early passaged cells, the doubling time for WKY cells was so much greater than for SHR cells ( $\sim 50 \mathrm{~h}$ vs. $24 \mathrm{~h}$ ) that it is possible that the WKY cells were still slowly proliferating while the SHR cells were more quiescent. Further studies such as cell cycle analysis will be necessary to delineate the role of this mechanism in altered $\mathrm{Na}^{+} / \mathrm{H}^{+}$exchange in SHR and WKY cells.

The $\mathrm{Na}^{+} / \mathrm{H}^{+}$exchanger under certain circumstances may mediate a large fraction of total VSMC Na${ }^{+}$influx $(22,24,26$, 40). To the extent that the primary VSMC subculture population reflects the in vivo cell population, differences in the extent of expression of the high $\mathrm{Na}^{+} / \mathrm{H}^{+}$exchange phenotype in vivo may explain certain alterations in SHR VSMC function. Recently, increased $\mathrm{Na}^{+} / \mathrm{H}^{+}$exchange in SHR platelets and lymphocytes has been demonstrated (25), suggesting that this phenotype may be a generalized abnormality and may represent a genetic trait. Of interest, platelets and red cells from patients with untreated hypertension have also been found to have enhanced $\mathrm{Na}^{+} / \mathrm{H}^{+}$exchange $(41,42)$. Thus the biochemical abnormalities that we have demonstrated in $\mathrm{Na}^{+} / \mathrm{H}^{+}$exchange in cultured SHR VSMC may be expressed in multiple cell types in both hypertensive animals and humans.

An increase in total systemic vascular resistance is a consistent finding in the SHR and has been proposed to be due to both enhanced vasoreactivity to a variety of stimuli $(9,10,43)$ and an increase in VSMC mass (12-14). A fundamental abnormality of SHR VSMC first described by Jones and colleagues (3) is an increased permeability of the sarcolemma to $\mathrm{Na}^{+}$. The finding that intravenous injection of amiloride or 6-iodo-amiloride at concentrations that block sodium channels (44) suggests that abnormal sodium channel activity plays an important role in SHR vasoreactivity especially in phasic changes. It is plausible that increased $\mathrm{Na}^{+} / \mathrm{H}^{+}$exchange may play a role not only in VSMC growth but also in VSMC tone via its effects on intracellular $\mathrm{pH}$ and $\mathrm{Na}^{+}$concentration. Intracellular alkalinization may increase the magnitude and duration of an agonist-mediated contractile response (45). Several important pathways involved in the contractile response including activity of actomyosin ATPase, $\mathrm{Ca}^{2+}$-calmodulin dissociation and myosin sensitivity to $\mathrm{Ca}^{2+}$ may be regulated by changes in $\mathrm{pH}(46)$. In particular $\mathrm{Na}^{+} / \mathrm{H}^{+}$exchange may play a role in chronic alterations in tone induced by vasoactive agonists, perhaps by modulating the magnitude or duration of the contractile response.

SHR VSMC have been shown to have increased phospholipase $\mathrm{C}$ activity (33), which is an important mediator of many vasoconstrictor agonists. We have recently demonstrated that intracellular alkalinization in VSMC enhances the sustained formation of diacylglycerol mediated by phospholipase $C$ (47). Because this may result in enhanced protein kinase $C$ activity (48) which itself has been proposed to stimulate contraction (49), it is possible that abnormal $\mathrm{Na}^{+} / \mathrm{H}^{+}$exchange might lead to enhanced tone via such a mechanism.

Maintenance of chronic elevation in vascular tone likely requires an increased VSMC intracellular calcium concentration. Blaustein (50) has proposed that a reduction of the $\mathrm{Na}^{+}$ gradient may decrease $\mathrm{Ca}^{2+}$ efflux via $\mathrm{Na}^{+} / \mathrm{Ca}^{2+}$ exchange and enhance contractility. We and others have recently shown that cultured rat aortic VSMC possess a $\mathrm{Na}^{+} / \mathrm{Ca}^{2+}$ exchange mechanism (51-53). The enhanced acid- and hormone-stimulated $\mathrm{Na}^{+} / \mathrm{H}^{+}$exchange mechanism in SHR VSMC demonstrated here would tend to decrease the $\mathrm{Na}^{+}$gradient (assuming extrusion of $\mathrm{Na}^{+}$by the $\mathrm{Na}^{+}, \mathrm{K}^{+}$-ATPase is not appropriately enhanced) and might be a potential mechanism to support the Blaustein hypothesis.

In summary, increased $\mathrm{Na}^{+} / \mathrm{H}^{+}$exchange in cultured $\mathrm{SHR}$ VSMC suggests that this alteration in function is genetically determined. Enhanced $\mathrm{Na}^{+} / \mathrm{H}^{+}$exchange in vivo may contribute to abnormal VSMC growth and play a role in vascular reactivity. These findings suggest a new mechanism to link abnormalities in SHR contractile state to abnormalities in SHR VSMC growth.

\section{Acknowledgments}

We would like to thank Ms. Susan McHale and Ms. Paula McColgan for excellent secretarial assistance, and William Atkinson for assistance in preparation of SHR and WKY VSMC.

This research was supported by National Institutes of Health grants HL-01831, HL-35013, HL-35664, and HL-36568 (Specialized Center of Research in Hypertension).

\section{References}

1. Hermsmeyer, K. 1976. Cellular basis for increased sensitivity of vascular smooth muscle in spontaneously hypertensive rats. Circ. Res. 38(Suppl. II):53-57. 
2. Friedman, S. M. 1979. Evidence for enhanced sodium transport in the tail artery of the spontaneously hypertensive rat. Hypertension (Dallas). 1:572-582.

3. Jones, A. W. 1974. Altered ion transport in large and small arteries from spontaneously hypertensive rats and the influence of calcium. Circ. Res. 34(Suppl. 1):117-122.

4. Tamura, H., L. Hopp, M. Kino, A. M. Tokushige, B. M. Searle, F. Khalil, and A. Aviv. $1986 . \mathrm{Na}^{+}-\mathrm{K}^{+}$regulation in cultured vascular smooth muscle cells of the spontaneously hypertensive rat. Am. J. Physiol. 250 (Cell Physiol. 19):C939-C947.

5. Nabika, T., P. A. Velletri, M. A. Beaven, J. Endo, and W. Lovenberg. 1985. Vasopressin induced calcium increases in smooth muscle cells from spontaneously hypertensive rats. Life Sci. 37:579584.

6. Clubb, F. J., Jr., P. D. Bell, J. D. Kriseman, and S. P. Bishop. 1987. Myocardial cell growth and blood pressure development in neonatal spontaneously hypertensive rats. Lab. Invest. 56:189-197.

7. Preuss, H. G., and H. Goldin. 1983. Serum renotropic activity and renal growth in spontaneously hypertensive rats. Kidney Int. 23:635-642.

8. Sen, S. 1987. Factors regulating myocardial hypertrophy in hypertension. Circ. Res. 75:81-84.

9. Webb, R. C., and P. M. Vanhoutte. 1979. Sensitivity to noradrenaline in isolated tail arteries from spontaneously hypertensive rats. Clin. Sci. 57(Suppl.):31s-33s.

10. Lais, L. T., and M. J. Brody. 1978. Vasoconstrictor hyperresponsiveness: an early pathogenic mechanism in the spontaneously hypertensive rat. Eur. J. Pharmacol. 17:178-189.

11. Folkow, B., M. Hallback, Y. Lundgren, and L. Weiss. 1970. Structurally based increase of flow resistance in spontaneously hypertensive rats. Acta. Physiol. Scand. 79:373-378.

12. Owens, G. K., and S. M. Schwartz. 1982. Alterations in vascular smooth muscle mass in the spontaneously hypertensive rat. Circ. Res. 51:280-289.

13. Mulvany, M. J., P. K. Hansen, and C. Aalkjaer. 1978. Direct evidence that the greater contractility of resistance vessels in spontaneously hypertensive rats is associated with a narrowed lumen, a thickened media, and an increased number of smooth muscle cell layers. Circ. Res. 43:854-864.

14. Owens, G. K., S. M. Schwartz, and M. McCanna. 1988. Evaluation of medial hypertrophy in resistance vessels of spontaneously hypertensive rats. Hypertension (Dallas). 11:198-207.

15. Yamori, Y., T. Igawa, M. Tagami, T. Kanbe, Y. Nara, M. Kihara, and $R$. Horie. 1984. Humoral trophic influence on cardiovascular structural changes in hypertension. Hypertension (Dallas). 6(Suppl. III):III-27-III-32.

16. Kanbe, T., Y. Nara, M. Tagami, and Y. Yamori. 1983. Studies of hypertension-induced vascular hypertrophy in cultured smooth muscle cells from spontaneously hypertensive rats. Hypertension (Dallas). 5:887-892.

17. Mahnensmith, R. L., and P. S. Aronson. 1985. The plasma membrane sodium-hydrogen exchanger and its role in physiological and pathophysiological processes. Circ. Res. 56:773-788.

18. Pouyssegur, J., C. Sadet, A. Frandri, G. L'Allemain, and S. Paris. 1984. A specific mutation abolishing $\mathrm{Na}^{+} / \mathrm{H}^{+}$antiport activity in hamster fibroblasts precludes growth at neutral and acidic pH. Proc. Natl. Acad. Sci. USA. 81:4833-4837.

19. Smith, J. B., and T. A. Brock. 1983. Analysis of angiotensin stimulated $\mathrm{Na}^{+}$transport in cultured smooth muscle from rat aorta. $J$. Cell Physiol. 114:284-290.

20. Owen, N. 1984. Platelet-derived growth factor stimulates $\mathrm{Na}^{+}$ influx in vascular smooth muscle cells. Am. J. Physiol. 247:C501C505.

21. Brock, T. A., R. W. Alexander, L. S. Ekstein, W. J. Atkinson, and M. A. Gimbrone, Jr. 1985. Angiotensin increases cytosolic free calcium in cultured vascular smooth muscle cells. Hypertension (Dallas). 7:105-109.

22. Berk, B. C., M. S. Aronow, T. A. Brock, E. J. Cragoe, M. A.
Gimbrone, Jr., and R. W. Alexander. 1987. Angiotensin II stimulated $\mathrm{Na}^{+} / \mathrm{H}^{+}$exchange in cultured vascular smooth muscle cells. J. Biol. Chem. 262:5057-5064.

23. Lowry, O. H., N. J. Rosebrough, A. L. Farr, and R. J. Randall. 1951. Protein measurement with the Folin phenol reagent. J. Biol. Chem. 193:265-275.

24. Vallega, G., M. L. Canessa, B. C. Berk, T. A. Brock, and R. W. Alexander. 1988. A kinetic study of the vascular smooth muscle $\mathrm{Na}^{+} / \mathrm{H}^{+}$exchanger and its activation by angiotensin II. Am. J. Physiol. 253:C751-758.

25. Feig, P. U., M. A. D’Occhio, and J. W. Boylan. 1987. Lymphocyte membrane sodium-proton exchange in spontaneously hypertensive rats. Hypertension (Dallas). 9:282-288.

26. Hatori, N., B. P. Fine, A. Nakamura, E. Cragoe, Jr., and A. Aviv. 1987. Angiotensin II effect on cytosolic $\mathrm{pH}$ in cultured rat vascular smooth muscle cells. J. Biol. Chem. 262:5073-5078.

27. Grinstein, S., S. Cohen, and A. Rothstein. 1984. Cytoplasmic $\mathrm{pH}$ regulation in thymic lymphocytes by an amiloride-sensitive $\mathrm{Na} / \mathrm{H}$ antiport. J. Gen. Physiol. 83:341-369.

28. Berk, B. C., T. A. Brock, M. A. Gimbrone, Jr., and R. W. Alexander. 1987. Early agonist-mediated ionic events in cultured vascular smooth muscle cells. J. Biol. Chem. 262:5065-5072.

29. Gunther, S., M. A. Gimbrone, Jr., and R. W. Alexander. 1980. Identification and characterization of the high affinity vascular angiotensin II receptor in rat mesenteric artery. Circ. Res. 47:278-286.

30. Schiffrin, E. L., F. S. Thome, and J. Genest. 1984. Vascular angiotensin II receptors in SHR. Hypertension (Dallas). 6:682-688.

31. Berk, B. C., H. M. Gordon, V. Vekshtein, M. B. Taubman, and R. W. Alexander. 1989. Angiotensin II stimulates protein synthesis in vascular smooth muscle independently of c-fos. Hypertension (Dallas). In press.

32. Geisterfer, A. A. T., M. J. Peach, G. K. Owens. 1988. Angiotensin II induces hypertrophy not hyperplasia, of cultured rat aortic smooth cells. Circ. Res. 62:749-756.

33. Vehara, Y., M. Yshii, T. Ishimitsu, and T. Sugimoto. 1988. Enhanced phospholipase $\mathrm{C}$ activity in the vascular wall of spontaneously hypertensive rats. Hypertension (Dallas). 11:28-33.

34. Bowen-Pope, D., M. W. Majeski, and R. Ross. 1987. Growth factors for vascular smooth muscle cells. In Vascular Smooth Muscle in Culture. Vol. 1. J. H. Campbell and G. R. Campbell, editors. CRC Press, Boca Raton, FL. 71-92.

35. Dzau, V. J., and G. H. Gibbons. 1987. Autocrine-paracrine mechanisms of vascular myocytes in systemic hypertension. Am. J. Cardiol. 60:991-1031.

36. Yamabe, H., and W. Lovenberg. 1974. Increased incorporation of ${ }^{14} \mathrm{C}$-lysine into vascular proteins of the spontaneously hypertensive rat. Eur. J. Pharmacol. 29:109-116.

37. Haudenschild, C. C., J. Grunwald, and A. V. Chobanian. 1985. Effects of hypertension on migration and proliferation of smooth muscle in culture. Hypertension (Dallas). 7(Suppl. I):I-101-I-104.

38. Ober, S. S., and A. B. Pardee. 1987. Intracellular pH is increased after transformation of chinese hamster embryo fibroblasts. Proc. Natl. Acad. Sci. USA. 84:2766-2770.

39. Viniegra, S., and C. A. Rabito. 1988. Development and polarization of the $\mathrm{Na}^{+} / \mathrm{H}^{+}$antiport system during reorganization of the LLC-PK ${ }_{\text {IA }}$ cells into an epithelial membrane. J. Biol. Chem. 263:In press.

40. Little, P. J., E. J. Cragoe, Jr., and A. Bobik. 1986. Na-H exchange is a major pathway for $\mathrm{Na}$ influx in rat vascular smooth muscle. Am. J. Physiol. 251:C707-C712.

41. Livne, A., J. W. Balfe, R. Veitch, A. Marquez-Julio, S. Grinstein, and $A$. Rothstein. 1987. Increased platelet $\mathrm{Na}^{+}-\mathrm{H}^{+}$exchange rates in essential hypertension application of a novel test. Lancet. i:533-536.

42. Morgan, K., M. Canessa, R. Goldzer, T. J. Moore, and G. H. Williams. 1988. Red cell $\mathrm{Na}^{+} / \mathrm{H}^{+}$exchange has a defective $\mathrm{H}^{+}$regulatory site in hypertensive patients with elevated $\mathrm{Na}^{+} / \mathrm{Li}^{+}$exchange. Clin. Res. 36:430a. (Abstr.) 
43. Ashida, T., Y. Yazaki, Y. Ohuchi, T. Tanaka, and M. Ikeda. 1983. Pressor responsiveness to vasopressin and angiotensin II in spontaneously hypertensive rats: effects of dietary sodium. Tohoku J. Exp. Med. 139:51-59.

44. Haddy, F. J., M. B. Pamnani, B. T. Swindall, J. Johnston and E. J. Cragoe. 1985. Sodium channels blockers are vasodilator as well as natriuretic and diuretic agents. Hypertension (Dallas). 7:T121-126.

45. Shepherd, J. T. 1983. Circulation to skeletal muscle. In Handbook of Physiology. Section II, Vol. II. Peripheral Circulation and Organ Blood Flow, Part I. J. T. Shepherd and F. M. Abboud, editors. Washington, DC, American Physiological Society. 319-370.

46. Wray, S. 1988. Smooth muscle intracellular pH: measurement, regulation and function. Am. J. Physiol. 254:C213-C225.

47. Griendling, K. K., B. C. Berk, and R. W. Alexander. 1988. Evidence that $\mathrm{Na}^{+} / \mathrm{H}^{+}$exchange regulates anyiotensin II-stimulated diacylglycerol accumulation in vascular smooth muscle cells. J. Biol. Chem. 263:10620-10624.
48. Nishizuka, Y. 1984. Turnover of inositol phospholipids and signal transduction. Science (Wash. DC). 225:1365-1370.

49. Danthuluri, N. R., and R. C. Deth. 1984. Phorbol ester-induced contraction of arterial smooth muscle and inhibition of alpha-adrenergic response. Biochem. Biophys. Res. Commun. 125:1103-1109.

50. Blaustein, M. P. 1984. Sodium transport and hypertension. Where are we going? Hypertension (Dallas). 6:445-453.

51. Nabel, E. G., B. C. Berk, T. A. Brock, and T. W. Smith. 1988. Na-Ca exchange in cultured vascular smooth muscle cells. Circ. Res. 62:486-493.

52. Smith, J. B., and L. Smith. 1987. Extracellular $\mathrm{Na}^{+}$dependence of changes in free $\mathrm{Ca}^{2+},{ }^{45} \mathrm{Ca}^{2+}$ efflux and total cell $\mathrm{Ca}^{2+}$ produced by angiotensin II in cultured arterial muscle cells. J. Biol. Chem. 262:17455-17461.

53. Matlib, M. A., A. Schwartz, and Y. Yamori. 1985. $\mathrm{A} \mathrm{Na}^{+}-\mathrm{Ca}^{2+}$ exchange process in isolated sarcolemmal membranes of mesenteric arteries from WKY and SHR rats. Am. J. Physiol. 249:C166-C172. 